\title{
Non-State Actors as Invisible Law Makers?- Domestic Implementation of Financial Action Task Force (FATF) Standards
}

\author{
Mari Takeuchi
}

There is no doubt that terrorism is one of the major challenges of the contemporary world that requires urgent and comprehensive action. One solution to this problem is regulating terrorism financing. Stopping the flow of funds or assets to terrorist organizations may contribute to preventing terrorist acts at an early stage. With respect to this, both binding international instruments, such as the International Convention for the Suppression of the Financing of Terrorism (Terrorist Financing Convention) ${ }^{1}$ and non-binding international standards are increasingly involved in such regulation.

This Chapter focuses on the non-binding international standards developed by the Financial Action Task Force (FATF). The FATF is a standard-setting body, composed of public regulatory authorities from member states, which aims to combat money-laundering and terrorist financing. As a transgovernmental network, ${ }^{2}$ the FATF dispenses with the many formalities followed by traditional international organizations. Despite the informality of its operation however, the non-binding standards developed by the FATF have been effectively implemented and have had tangible effects domestically, owing mainly to its own monitoring mechanism.

The trend of governmental networks' involvement in the international lawmaking process has been, for quite some time, the subject of scholarly projects, such as those concerning international relations in terms of disaggregated

1 International Convention for the Suppression of the Financing of Terrorism (Terrorist Financing Convention), adopted 9 December 1999, entered into force 10 April 2002, 2178 UNTS 229 .

2 A transgovernmental network in general means a form of cooperation based on loosely structured ties rather than binding agreements, where national public regulatory authorities engage in the business of exchange information, harmonizing their rules, or setting standards or other norms, etc. As a network of public regulatory authorities, it's scope is narrower than transnational network which may comprise both a network of government officials and that of private entities. 
sovereignty ${ }^{3}$ and global administrative law in terms of informal international law-making. ${ }^{4}$ While being informed and inspired by those research projects, this Chapter aims to explore a non-state actor dimension of the FATF. The term 'dimension'5 is chosen to highlight the dual nature of the FATF.

It is difficult to separate transgovernmental networks from states; indeed, the FATF is a forum of government officials whose decisions are reached by consensus that are regarded as collective decisions made by member states rather than that of a body that possesses its own distinct will. ${ }^{6}$ Thus, it may have a separate existence from states 'in fact, but not in law.' ${ }^{7}$ However, the FATF has achieved certain 'internal' abilities to affect members' legal obligations owing to its unique monitoring mechanism and the 'external' capacity to spread its norms globally through cooperative arrangements with other international and regional bodies. While these functions are performed in informal settings and thus remain de facto powers, they represent the FATF's managerial aspect, which may imply certain autonomy in relation to member states (non-state actor dimension), rather than its 'agora' function. Admittedly, such an understanding of autonomy is 'nuanced and incremental', ${ }^{8}$ but this reflects the twilight status the FATF has maintained. It will be argued that this dual nature of the FATF has facilitated the effective implementation of its non-binding standards and the harmonization of relevant laws within domestic legal systems.

3 Pioneering works are provided by international relation scholarship. Anne-Marie Slaughter, A New World Order (Princeton University Press, Princeton, 2004); Kal Raustiala, 'The Architecture of International Cooperation: Transgovernmental Networks and the Future of International Law' (2002) 43 Virginia Journal of International Law, 1; Kal Raustiala, 'Transnational Networks: Past and Present' (2009) 43 International Lawyer, 205.

4 Benedict Kingsbury, Nico Krisch, and Richard B. Stewart, 'The Emergence of Global Administrative Law', (2005) 68 Law and Contemporary Problems, 17; Joost Pauwelyn, Ramses A. Wessel, and Jan Wouters, Informal International Lawmaking (Oxford University Press, Oxford, 2012).

5 For the terminology of 'non-state actor dimention', see Ramses A Wessel, 'International Governmental Organisations as Non-State Actors' in Math Noortmann, August Reinisch, and Cedric Ryngaert, Non-State Actors in International Law (Hart Publishing, Oxford, 2015), 185, 195.

6 Tarcisio Gazzini, 'The Relationship between International Legal Personality and the Autonomy of International Organizations' in Richard Collins and Nigel D. White, International organizations and the idea of autonomy (Routledge, Abingdon, 2011), 196, 202.

7 Nigel D. White, 'Layers of autonomy in the UN system' in ibid, 298, 300.

8 For the nuanced and incremental aspect of autonomy, see Duncan French, 'Autonomy in international environmental law and governance' in Richard Collins and Nigel D. White, note 6, 366,376 . Such nuanced conception of autonomy is also advocated by Gazzini, who contrasts the question of autonomy of international organisations against the question of international legal personality and argues that the former is a matter of degree whereas the latter calls for a yes or no answer. Gazzini, note 6, 207-208. 
Against this background, this Chapter aims to explore non-state actor dimensions of the FATF and their impact upon the existing system of international law-making. While the FATF's standards cover areas other than terrorist financing, it is appropriate to focus on this area for the purpose of this Chapter. The FATF's standards (non-binding norms) are designed to be closely related to the Terrorist Financing Convention provisions (binding norms) and, as is illustrated in this Chapter, the effective implementation of the FATF's standards appear to enhance the implementation of the Convention by adding substance or depth to a treaty provision or even expanding the scope of an obligation without the involvement of international treaty authorities. This challenges our understanding of the structure of international law-making.

The structure of this Chapter is as follows: Section 2 maps the current international norms of countering terrorist financing, (the Terrorist Financing Convention). Section 3 examines the structure of the FATF Standards in relation to the Terrorist Financing Convention (3.1) and how the non-state actor dimension of the FATF functions in complementing the Convention (3.2). Section 4 furtuer examines how the non-state actor dimension of the FATF generates material consequences domestically (4.1) and internationally (4.2). This Chapter will end with some concluding remarks.

\section{The Traditional Framework}

The International Convention for the Suppression of the Financing of Terrorism (Terrorist Financing Convention) is currently the only universally binding instrument relating to terrorism financing. The Convention covers two areas of regulation. First, it regulates the criminalization of the financing of terrorism. Articles 1 and 2 define 'funds' and the 'offence of providing and collecting funds', respectively, and Article 4 obliges State Parties to criminalize the acts of providing and collecting funds. The Convention further imposes an obligation upon State Parties to establish jurisdiction over the Convention offences (Article 7), accompanied by the so-called obligation of 'aut dedere aut judicare (to extradite or prosecute)' (Article 10), ${ }^{9}$ thereby aligning itself with other counter terrorism conventions. ${ }^{10}$

9 Under this obligation, states are required to establish jurisdiction in cases where the alleged offender is present in its territory and it does not extradite that person to any of the State Parties that have established jurisdiction in accordance with the Convention. For the obligation of 'aut dedere aut judicare' in general, see, Raphael van Steenberghe, 'The Obligation to Extradite or Prosecute' (2011) 9Journal of International Criminal Justice, 1089.

10 In fact, most of the counter terrorism conventions have adopted the formula established by the Convention for the Suppression of Unlawful Seizure of Aircraft (1970), in which 
Second, the Convention requires State Parties to take certain preventive measures in countering terrorism financing under the rubric of obligation to cooperate. These include measures requiring financial institutions and 'other professions involved in financial transactions'11 to utilize due diligence for the identification of customers and the reporting of suspicious transactions (Article 18).

The object and purpose of the Terrorist Financing Convention is to regulate the supply and collection of funds for the perpetration of terrorist acts, rather than the perpetration of a terrorist act itself. This serves to prevent terrorist activities at an earlier stage. In addition, mobilizing private entities that have direct contact with the relevant financial transactions may facilitate the effectiveness of prevention.

Conversely, the Terrorist Financing Convention has certain limits. First, it has a limit common to all treaties: that is, a treaty only binds a state that gives consent to it (Article 26 of the 1969 Vienna Convention on the Law of Treaties). In addition, if a treaty sets a requirement such as number of ratifications for it to enter into force - which is usually the case in modern multilateral treaties - it does not bind any state until that requirement is met (and it enters into force). These features may constitute an obstacle to the broad and prompt implementation of a treaty, which is particularly crucial in the effective countering of terrorism. In fact, the Terrorist Financing Convention had not entered into force at the time of the 2001 September 11 attacks because it had by then attracted only 4 out of the the required 22 ratifications provided for in Article 26 of the Convention. ${ }^{12}$

(i) the definition of offences is provided by a treaty itself, (ii) state parties are required to establish jurisdiction in cases not only where they have a link to the offence but also where the alleged offender is present in its territory and it does not extradite that person to State parties that have established jurisdiction in accordance with the treaty, and (iii) it is required to adopt a mechanism of 'aut dedere aut judicare' which would secure criminal proceedings to be initiated wherever the alleged offender is found.

11 The Convention does not specify what professions are covered by this term. This 'deficiency' is ostensibly complemented by the FATF Standards, which will be discussed in Section 3 .

12 It is worth noting that the Security Council Resolution 1373 that was adopted two weeks after the September 11 attacks almost mirrored the object and purpose as well as the contents of the Terrorist Financing Convention. Adopted as a 'decision' under the Chapter VII, it binds all Member States. Owing to its general character of obligation and its binding nature, Resolution 1373 has been dubbed a 'legislative' resolution. Since the adoption of the Resolution 1373, the Terrorist Financing Convention had rapidly attracted ratifications, and it entered into force on 10 April 2002. The Security Council's 'legislation' thus temporarily compensated the deficiencies of the Convention. For 'legislative power' of 
Second, the effective implementation of the Terrorist Financing Convention is limited by the wording of its obligations. For example, while the obligation to criminalize the supply and collection of funds for terrorist activities is formulated using strong mandatory language with precise content ('shall adopt certain measures'), this is not the case with respect to the obligation to require private entities to take certain due diligence measures. In fact, the latter obligation can be criticised for being too general or weak, as it is stipulated as an obligation to cooperate and formulated using an ambiguous term ('shall consider adopting certain measures'). Moreover, the Convention does not provide for an enforcement mechanism, such as monitoring bodies comparable to those established under human rights conventions ${ }^{13}$ or compliance mechanisms created by treaties in the field of environmental protection. ${ }^{14}$ Rather, it is only through the settlement of disputes between State Parties concerning the interpretation or application of the Convention that the non-implementation of obligations can be addressed. However, the invocation of the dispute settlement clause rarely occurs in the area of counter-terrorism conventions. Even when a Party does invoke the dispute settlement clause, the outcome of dispute settlement may depend heavily on the background and context of each dispute, which may not lead to a uniform implementation of the Convention provisions among state parties.

Given these deficiencies in the substance of obligations and lack of enforcement provisions, some may argue that the rules contained in the Terrorist Financing Convention should be categorized as 'soft' obligations, despite their binding nature. For example, Christine Chinkin maintains that if a treaty is to be regarded as "hard", it must be precisely worded and specify the exact obligations undertaken or the rights granted.15 For such analysts, it is not the formality of instruments but the specificity or preciseness of its rules that make it 'hard'. Conversely, rules contained in non-binding instruments can be seen generating 'hard' obligations if they are formulated in mandatory and specific terms. ${ }^{16}$

the Security Council, see Stephen Talmon, 'The Security Council as World Legislature' (2005) 99 American Journal of International Law, 175, 176-177. For a more cautious view, see Matthew Happold, 'Security Council Resolution 1373 and the Constitution of the United Nations' (2003) 16 Leiden Journal of International Law, 593, 6o7.

13 E.g. Human Rights Committee established under the 1969 International Covenant on Civil and Political Rights.

14 E.g. 1992 United Nations Framework Convention on Climate Change.

15 Christine Chinkin, 'The Challenge of Soft Law: Development and Change in International Law' (1989) 38 International and Comparative Law Quarterly, 850, 851.

16 Friedrich Kratochwil, Rules, Norms, and Decisions: On the Conditions of Practical and Legal Reasoning in International Relations and Domestic Affairs (Cambridge University Press, Cambridge, 1989), 200-201. 
Indeed, there has been a growing trend of pluralization of norms, and the concept of soft law can be seen as an effort to capture such phenomenon by creating a category between binding law and no law. In fact, the term itself seems well-established in scholarship. ${ }^{17}$ Yet the concept of soft law is rather misleading, especially when it situates both binding and non-binding instruments within the same category. The formality of an instrument is important in that it requires a formal act of consent from a state for it to have legal effect upon that state, which distinguishes binding law from no law. The formality of an instrument is also important in terms of the domestic procedure, as the act of consent is in many cases premised on an approval by legislative organs at the domestic level. ${ }^{18}$

While retaining the distinction between binding law and no law is thus essential as a starting point, it should nevertheless be admitted that a more elaborate framework is required to capture the pluralization of norms where binding norms and non-binding norms overlap and interact with each other. In this regard, the tripartite conceptual framework advanced by Kal Raustiala is particularly useful, in which legality (referring to the legal quality of instrument, that is, whether it is binding or not), substance (referring to the depth of commitment contained in an agreement, that is, to what extent an agreement requires a state to deviate from the status quo), and structure (referring to the mechanism for monitoring and enforcing performance, assessed in light of its strength) are designated as features constituting international agreements. ${ }^{19}$ Indeed, it does not only distinguish binding norms from non-binding ones, but also enables an assessment of 'trade-offs' that exist between these norms. In light of this framework, the Terrorist Financing Convention can be seen as a legally binding instrument with shallow substance and weak structure. Grounded in this assessment, the next section turns to the FATF Standards, which are non-binding but ostensibly more effective in terms of substance and structure than the Terrorist Financing Convention.

17 Alan Boyle, 'Soft Law in International Law Making', in Malcolm Evans, International Law (3rd edn, Oxford University Press, Oxford, 2010) 122, 123-124; Kenneth W. Abbot and Duncan Snidal, 'Hard and Soft Law in International Governance' (2000) 54 International Organization, 421, 423; Jutta Brunnée, 'The Sources of International Environmental Law: Interactional Law', in Samantha Besson and Jean d'Aspremont, Oxford Handbook on the Sources of International Law (Oxford University Press, New York, 2017), 96o, 977-978.

18 See e.g. Curtis A. Bradley, International Law in the U.S. Legal System (2nd edn, Oxford University Press, New York, 2015), 32-34.

19 Kal Raustiala, 'Form and Substance in International Agreements' (2005) 99 American Journal of International Law, 581, 583-585. 


\section{Complementing the Traditional Framework - the FATF and Its Non-State Actor Dimension}

\subsection{The Overview of the FATF}

The FATF was established in 1989 by a ministerial declaration at the $\mathrm{G}_{7}$ summit held in Paris, ${ }^{20}$ initially to develop measures to combat money laundering, then extending its mandate to include efforts to combat terrorist financing in 2001 and to counter financing of the proliferation of weapons of mass destruction in 2012. As of January 2020, the FATF comprises 37 member countries $^{21}$ and two regional bodies (the European Commission and the Gulf Cooperation Council). As a standard setting body, the FATF has issued a series of Recommendations, ${ }^{22}$ that are supplemented by their Interpretive Notes and the applicable definitions in the General Glossary. These instruments as a whole form the FATF Standards, against which, states' implementation of terrorist financing measures can be evaluated.

While lacking binding force, the FATF Standards contain elaborate and specific rules, which are closely related to the Terrorist Financing Convention. For the purpose of this Chapter, it is useful to illustrate the relationship between the FATF Standards and the Convention, before exploring the non-state actor dimention of the FATF.

In relation to the Terrorist Financing Convention, the FATF Standards involve two types of rules. On the one hand, some Standards comprise rules that overlap with treaty provisions. With regard to the criminalising of terrorist financing for example, FATF Recommendation 5 explicitly refers to the Terrorist Financing Convention as the basis of the obligation to criminalise terrorist financing and the Interpretive Note to Recommendation 5 includes paragraphs that also reflect relevant treaty provisions (Articles 2 and 4 of the Convention).

20 Basic materials of the FATF can be obtained from the FATF's website, at https://www.fatfgafi.org/ (accessed o9/o3/20).

21 The original members are the G7 members (US, Germany, France, UK, Italy, Canada, Japan) and some industrialized states (Sweden, the Netherland, Belgium, Luxemburg, Switzerland, Austria, Spain, and Australia). Since then, it has gradually expanded its members as follows: in 1991, Denmark, Finland, Greece, Ireland, NZ, Norway, Bahrain, Qatar, and Hong-Kong; in 1992, Iceland and Singapore; in 200o, Argentine, Brazil, and Mexico; in 2003, Russia and South Africa; in 2007, China; in 2009, South Korea; in 2010, India; in 2016, Malaysia; in 2018, Israel; in 2019, Saudi Arabia.

22 The 2012 Recommendations in which terrorist financing was fully integrated with the measures against money laundering currently constitute the basis for implementation and evaluation and the assessment in this chapter is based on them. FATF Recommendations 2012, available at https://www.fatf-gafi.org/media/fatf/documents/recommendations/ pdfs/FATF\%2ORecommendations\%2O2012.pdf (accessed o9/o3/2O). 
In addition, the definition of 'funds' included in the General Glossary incorporates almost all of the definition of 'funds' under Article 1(1) of the Convention. In other words, the FATF Standards as a whole mirror the substance of the Convention with regard to the obligation to criminalise terrorist financing acts.

On the other hand, other Standards enhance the Convention by adding substance or depth to a treaty provision or even expanding the scope of treaty norms. This aspect is related in particular to the measures requiring financial institutions and other professionals to take due diligence measures. As to substance-adding provisions, for instance, while the Convention does not specify which private entities are covered by 'other professions involved in financial transactions', FATF Recommendation 22 designates five categories of professions ${ }^{23}$ which are required to comply with customer due diligence and record-keeping in certain situations relating to financial transactions. Likewise, Recommendation 23 provides that a suspicious transactions reporting (STR) mechanism is applied to these professions. Seen in this context, the function of the FATF Standards in relation to the Terrorist Financing Convention is similar to, if not equated to, that of the 1997 Kyoto Protocol to the 1992 United Nations Framework Convention on the Climate Change, in which the former instrument provides substance to the obligation of 'common but differentiated responsibility' as stipulated in the latter. As to expanding existing treaty provisions, Recommendation 12 creates a new category of 'politically exposed persons' to whom enhanced customer due diligence measures are to be applied. While framed in non-mandatory terms ('should'), these substantiating and expanding provisions supplemented by the corresponding Interpretive Notes and Glossary are precise and unambiguous enough to identify what sort of measures are required. Moreover, states are also required to take material measures in the form of legal or other enforceable means, ${ }^{24}$ which can be regarded as deep in substance in light of Raustiala's tripartite conceptual framework.

\section{2}

\section{The Non-State Actor Dimension of the FATF}

Having thus detailed the FATF Recommendations, this Section now turns to the FATF's non-state actor dimension, which is also related to a structure in the

23 They are dubbed 'Designated Non-Financial Businesses and Professions (DNFBPs)' which covers: (a) casinos, (b) real estate agents, (c) dealers in precious metals and dealers in precious stones, (d) lawyers, notaries, other independent legal professionals and accountants, and (e) trust and company service providers.

24 See Note to Legal Basis of Required on Financial Institutions and DNFBP s, included in the FATF Recommendation (2012). Even the terms 'law' and 'enforceable means' are defined in that Note. 
above tripartite framework. Admittedly, it is difficult to separate the FATF from its member states. In fact, when Anne-Marie Slaugher illustrates the trend of transgoverenmental network as a phenomenon of disaggregated sovereignty or sovereignty as the capacity to participate in the networks, she suggests that such trend will 'bolster the power of the state as the primary actor in the international system. ${ }^{25}$ All decisions are made by consensus at the Plenary, ${ }^{26}$ which means that members have a right to veto FATF's decisions, thus making its functioning entirely dependent on members' collective will. ${ }^{27}$ Moreover, the FATF has operated under a limited life span as it requires a specific decision by its Ministers to continue. ${ }^{28}$ While the ministers of member states adopted an open-ended Mandate at its 3oth anniversary in 2019, this revised Mandate itself makes it clear that it is 'not intended to create any legal rights or obligations' and that 'the FATF is accountable to its Ministers'.29 This indicates that the FATF remains a governmental network rather than an international organisation possessing its own international legal personality. ${ }^{30}$

However, the FATF has some managerial aspects, which may imply certain autonomy in relation to its member states (the non-state actor dimension). In fact, the FATF has achieved certain 'internal' abilities that can affect members' legal obligations along with an 'external' capacity to spread its norms globally.

25 Slaughter, note $3,269-270$.

26 This informality allows the FATF to make decisions in a rapid manner 'where emerging threats are identified or urgent action is needed'. See Alain Damais, 'The Financial Action Task Force' in Wouter H. Muller, Christian H. Kälin and John G. Goldsworth, Anti-Money Laundering: International Law and Practice (John Wiley \& Sons Ltd, Chichester, 2007), 69, 73. See also Raustiala, note 3, 30; Chris Brummer, 'Why Soft Law Dominates International Finance - and Not Trade' (2010) 13 Journal of International Economic Law, 623, 634.

27 Gazzini, note 6, 202. However, it should be noted that the decision of the participating regulator to accept the particular standard or lawmaking in question does not constitute expression of state consent, as these agents are often not empowered with the legal authority to engage their states under international law. Henrique Choer Moraes, 'International Lawmaking by Transnational Networks: Using Domestic Coordination to Address Asymmetries In Participation' (2016) 19 Journal of International Economic Law, 821, 827. See also Kenneth Blazejewski, 'The FATF and its Institutional Partners: Improving the Effectiveness and Accountability of Transgovernmental Networks' (2008) 22 Temple International \& Comparative Law Journal, $1,8$.

28 Damais, note $26,72$.

29 FATF's Mandate (12 April 2019), paras. 48 and 5o, available at, http://www.fatf-gafi.org/media/ fatf/content/images/FATF-Ministerial-Declaration-Mandate.pdf (accessed og/o3/2o).

30 In order for an entity to be an international organisation, it should (1) be founded on an international agreement; (2) have at least one organ with a will of its own; and (3) be established under international law. See, Henry G. Schermers and Niels M. Blokker, International Institutional Law (6th rev. edn, Brill Nijhoff, Leiden Boston, 2018), 41. 
On the one hand, the FATF's internal abilities are mainly attributable to its unique monitoring mechanism, which makes the FATF 'one of the most successful and ambitious international standard setters.' ${ }^{31}$ Within this mechanism, a mutual evaluation process comprises the first step in which each member country is examined based on an on-site visit by a team of experts from other member countries (assessors). Both the criteria for assessing compliance with each of the FATF Recommendations and the procedure for evaluation are stipulated in detail in documents that are adopted and regularly updated by the Plenary. ${ }^{32}$ It is worth noting the managerial aspect of the FAT F that is revealed when a mutual evaluation report is finalised by assessors at the Plenary. At this stage, consensus is required to overrule any of the draft findings by the assessors (the so-called negative consensus) while the assessed state has no vote. Put differently, no member state, including the assessed state has a right to veto the draft findings. The final report is regarded a report of the FATF and not simply a report by the assessors.

Moreover, such an evaluation is accompanied by some institutionalised processes, which show another managerial aspect of the FATF. After the adoption of an assessment report, all member states are placed in follow-up as the second step in which members with significant deficiencies are subject to an enhanced follow-up that triggers 'a gradual approach aimed at enhancing peer pressure. ${ }^{33}$ This involves the following steps: (1) letters sent from the FATF to the failed jurisdiction, (2) a visit from the High Level Commission to the failed jurisdiction, (3) the designation of the country concerned as a non-cooperative country and (4) the suspension of membership. ${ }^{34}$ It is worth drawing particular attention to the third step, known as the 'name and shame' strategy. Being named a failed jurisdiction may incur reputational costs for regulators by 'isolating [them] both institutionally (and at times, personally) in the international community'. ${ }^{35}$ Moreover, this may also create market costs by portraying the market in a failed jurisdiction as a 'risky and dishonourable

31 Chris Brummer, Soft Law and the Global Financial System (2nd edn, Cambridge University Press, New York, 2015), 89 .

32 For the criteria for the assessment, see FATF, Methodology (updated October 2019), available at: http://www.fatf-gafi.org/media/fatf/documents/methodology/FATF\%2O Methodology\%2022\%20Feb\%202013.pdf (accessed o9/o3/20); For the evaluation procedure, see FATF, Procedures for the FATF Fourth Round of AML/CFT Mutual Evaluations [hereinafter Procedures] (updated October 2019), http://www.fatf-gafi.org/media/fatf/ documents/methodology/FATF-4th-Round-Procedures.pdf (accessed o9/o3/20).

33 Damais, note 26, 73 .

34 Procedures, note 32, para.91.

35 Brummer, note $26,640$. 
place to do business. ${ }^{36}$ It should be noted that the FATF institutionalises these risks in its own monitoring mechanism by vesting itself with powers to trigger countermeasures from member states against a failed jurisdiction and to require enhanced due diligence measures against the financial institutions of the failed jurisdiction (Recommendation 19). ${ }^{37}$ Put simply, it is barking (naming and shaming) combined with the fear of biting (sanctions), that actually creates material consequences in the implementation of the FATF Standards.

Meanwhile, its 'external' capacity to spread its norms globally is attributable to its cooperative arrangements with other international and regional bodies. While the FATF has restricted its membership to countries that have the intention and capacity to implement its standards, it has also encouraged the development of regional groups that have adopted a similar form, functions and procedures to those of the FATF. Today, nine FATF-style regional bodies have been created and are recognised by the FATF, ${ }^{38}$ which means that over 190 jurisdictions have committed to implementing the FATF's standards. It is worth noting that, while there is no organisational hierarchy between the FATF and these regional bodies, the FATF has certain de facto governing power over them. First, only the FATF sets standards. While each regional body conducts FATF-style mutual evaluations, these evaluations should be subject to quality and consistency review in accordance with the procedures set by the FATF prior to publication. ${ }^{39}$ The reports endorsed by the FATF should also be published on the FATF website. ${ }^{40}$ Moreover, when significant deficiencies are found within member states of these regional bodies in mutual evaluation processes, such states will be subject to a review process conducted by the International Co-operation Review Group established under the FATF. These mechanisms are loosely coordinated and thus informal, but they add the appearance that the FATF has the authority to govern these regional bodies' activities.

Alongside these arrangements between the FATF and regional bodies, the FATF has obtained considerable support from international bodies such as

\footnotetext{
$36 \quad$ Ibid, 641 .

37 Admittedly, it is designated as a last resort, because jurisdictions that are to be subject to sanctions should be 'higher-risk countries', rather than 'non-cooperative countries'.

38 The relation between the FATF and the regional bodies is stipulated in High-Level Principles for the relationship between the FATF and the FATF-style regional bodies, updated February 2019, available at: http://www.fatf-gafi.org/media/fatf/documents/ High-Level\%2oPrinciples\%2oand\%2oObjectives\%2ofor\%2oFATF\%2oand\%2oFSRBs. pdf (accessed o9/o3/20).

39 Ibid, para.35. Inconsistent and poor quality mutual evaluation reports will not be published, and the jurisdiction will not be considered to have been assessed. Ibid, para.36.
} 
the UN Security Council and G2O. For instance, paragraph 4 of the Security Council Resolution 2462 (2019) strongly urges all states to implement the 'comprehensive international standards' embodied in the FATF recommendations and its interpretive notes. ${ }^{41}$ Likewise, in its Osaka Declaration, G2o leaders welcomed Security Council Resolution 2462 and 'call for the full, effective and swift implementation of the FATF Standards. ${ }^{2}$ Such a powerful endorsement would increase the reputational costs of non-compliance and strengthen the FATF's 'external' capacity to spread its norms globally. ${ }^{43}$

In summary, the FATF Standards can be regarded as lacking legal quality because of their non-binding nature but they have deep substance and strong structure in light of the tripartite conceptual framework. Notably, this structural strength is rooted in the non-state actor dimension of the FATF that generates the FATF's 'internal' abilities that can affect members' legal obligations alongside the 'external' capacity to spread its norms globally.

Beyond the Traditional Framework-Domestic Implementation of the FATF Standards and Its Impact upon International Law-Making

Building on the analysis of the previous section, this section further examines how the non-state actor dimension of the FATF generates material consequences both domestically (4.1) and internationally (4.2).

\subsection{Domestic Implementations of the FATF Standards}

To examine the process of domestic implementation of the FATF Standards, it is useful to begin by assessing how their three features (non-binding nature, depth of substance and strength in structure) work in the process of domestic implementation.

As for the non-binding nature of the FATF Standards, it should be pointed out that it is exactly because of this lack of bindingness that the FATF Standards

41 UNSC Resolution 2462 (2019) Threats to international peace and security caused by terrorist acts: Preventing and combatting the financing of terrorism.

42 G2o Osaka Leaders Declaration (July 2019), available at https://g2o.org/en/g2o/ Documents/2019-Japan-G20\%20Osaka\%2oLeaders\%2oDeclaration.pdf (accessed o9/ 03/20).

43 Such endorsement can be partly based on that the FATF was established by a ministerial declaration at the Summit, thus being a 'minister network', which distinguishes itself from regulators networks. See Stavros Gadinis, 'Three Pathways to Global Standards: Private, Regulator and Ministry Networks' (2015) 109 American Journal of International Law, 1,4 . 
are rarely subject to political scrutiny, such as parliamentary approval, ${ }^{44}$ at the stage of incorporation. In fact, the FATF Standards do not meet the threshold to qualify as a treaty or a legally enforceable commitment. Admittedly, they are usually implemented through enactment or amendment of legislation or promulgation of regulations, and in that respect go through a recognition process at the domestic level. However, given that the FATF Standards have a strong compliance-pull, it could be argued that the issue is not necessarily whether these standards could be accepted but rather how they should be implemented.

While thus bypassing parliamentary approval when incorporated into domestic legal systems, the FATF Standards tend to be explicitly and positively referred to at the stage of enactment of legislation or regulation that implements these standards. This may facilitate their incorporation and also add a 'legitimacy' to originally non-binding and informal norms.

The most institutionalized example for such positive reference is provided by the Council of Europe Convention of 16 March, 2005, on Laundering, Search, Seizure and Confiscation of the Proceeds from Crime and on the Financing of Terrorism, ${ }^{45}$ which explicitly refers to the FATF Recommendations in Article 13 as one of the 'applicable international standards to be taken due account of' when a party to the Convention enacts necessary legislation. By being referred to in a body of the convention rather than its preamble, this reference may serve to narrow the margin of discretion of member states not to take account of the FATF Recommendations.

The FATF Standards are also positively referred to by domestic legislation or regulation. Australia's Anti-Money Laundering and Counter-Terrorism Financing Act $2006^{46}$ lists the FATF Recommendations as one of the instruments that reflect 'international concern', along with a series of conventions as well as relevant UN resolutions. In a similar vein, a guideline issued by Japan's Financial

44 Admittedly, there are certain international agreements that are not submitted for parliamentary approval, yet still be subject to some political scrutiny. For instance, 1 U.S. Code $\S 112 \mathrm{~b}(\mathrm{a})$ provides that the US Secretary of State is required to transmit to the US Congress the text of any 'international agreement' other than a 'treaty' (a 'treaty' is required to be submitted for approval by $2 / 3$ of the US Senate under Article II:2 of the US Constitution). Nevertheless, the FATF Standards still avoid such scrutiny, because 'international agreement' is assumed to refer to legally binding instruments under international law and not non-binding instruments.

45 Convention of 16 March, 2005, on Laundering, Search, Seizure and Confiscation of the Proceeds from Crime and on the Financing of Terrorism Council of Europe Treaty Series, No.198, adopted on 16 May 2005. Anti-Money Laundering and Counter-Terrorism Financing Act No.169, 2006 (Australia). 
Service Agency (FSA) in February 2018, in preparing for the fourth mutual evaluation process of the FATF, refers to the FATF as one of the international organizations, alongside the Basel Committee on Banking Supervision, whose instruments should be 'taken full account of'. Given that the FATF Standards usually bypass political scrutiny at the incorporation stage, it is as if these Standards entered into neighbour's house from a backyard without being noticed, but then found themselves offered a guest of honour seat at a dinner table.

These explicit and positive types of reference are partly understood by the way governmental officials engage in the formulation of international standards. With regard to international standards set forth by a governmental network like the FATF, governmental officials directly engage in the formulation of standards at the international level and, accordingly, act as advocates of those standards at the domestic level. ${ }^{47}$ Indeed, because of the international standards' highly technical character, it is usually these governmental officials and not legislators that are substantively involved in their enactment under domestic law. 48

As for depth in substance, the detailed and specific wording of the FATF Standards allow them to be precisely reflected in domestic legislation. As domestic implementing legislation must be regularly and thoroughly checked under the monitoring mechanism with a strong structure, the FATF Standards have been effectively implemented and have had tangible effects domestically.

In this regard, Japan's experience concerning the Act on the Punishment of Financing of Offences of Public Intimidation (Terrorist Financing Act) ${ }^{49}$ represents a salient example. This Act was originally enacted to implement the Terrorist Financing Convention, but it is also relevant to the implementation of the FATF Standards, as the latter mirrors the definition of terms under the Convention. During the third mutual evaluation process, the Terrorist Financing Act was subject to comprehensive scrutiny and the evaluation report for Japan concluded that Japan's compliance with the FATF Standards were only partial, because the definition of 'funds' under the domestic legislation was too limited. ${ }^{50}$ Japan understood that its definition of funds met the Convention's

47 Richard B. Stewart, 'The Global Regulatory Challenge to U.S. Administrative Law' (2006) 37 N.Y.U. Journal on International law and Politics, 695, 704.

48 Moraes, note 27, 821 .

49 Act on the Punishment of Financing of Offences of Public Intimidation (Terrorist Financing Act) No. 67 of June 12, 2002. English translation is available at: http://www. japaneselawtranslation.go.jp/law/detail_main?vm=04\&id=2977 (accessed o9/o3/20).

$5^{\circ}$ FATF, Third Mutual Evaluation Report of Japan (17 November 2008), available at: http:// www.fatf-gafi.org/media/fatf/documents/reports/mer/MER\%20Japan\%2ofull.pdf (accessed o9/03/20). 
requirement in light of the treaty negotiation process. However, the FATF did not accept Japan's position and issued a statement during its Plenary in June 2014, urging Japan to enact adequate anti-money laundering and counter terrorist financing legislation. ${ }^{51}$ Averse to being listed as a non-compliant jurisdiction, Japan eventually amended the Terrorist Financing Act, to meet the FATF's requirement by broadening the range of prohibited assets to include land, buildings, goods, services and other interests, as well as expanding the scope of prohibited conduct. ${ }^{52}$ The FATF is not a body established under the Terrorist Financing Convention and has no power to interpret or apply the Convention, nor is its statement binding. Nevertheless, it still effectively induces states to adopt in their domestic legislation precisely what it regards as a proper interpretation of the Convention, owing to its structure which reflects its managerial aspect (the non-state actor dimension).

While these three features of the FATF Standards thus serve to facilitate their domestic implementation, implementation does not always proceed without obstacles. In fact, the inclusion of lawyers in the suspicious transaction reporting (STR) mechanism required by FATF Recommendation 23 has met with challenges from stakeholders - in this case lawyers - in various jurisdictions, mainly because it allegedly conflicts with fundamental principles of human rights law. ${ }^{53}$ For instance, the Japan Federation of Bar Associations (JFBA) launched a public campaign against a government initiative to include lawyers under the STR mechanism, claiming that it would be incompatible with attorney-client privilege as well as with the principle of legal independence. As a result, Article 12 of the Act on Prevention of Transfer of Criminal Proceeds 2007, which implements the FATF Standards, exempts lawyers from the duty of reporting suspicious transactions, and refers to the lawyer's duty of customer due diligence and record keeping as being governed by the JFBA's internal rules (JFBA Rules). ${ }^{54}$ Likewise, in Canada, the Proceeds of Crime

51 Outcomes from the meeting of the FATF Plenary, Paris, 25-27 June 2014, available at: http://www.fatf-gafi.org/publications/fatfgeneral/documents/plenary-outcomes-jun2014.html (accessed o9/03/20).

$5^{2}$ As for the amended text and discussion in the Diet, see Mari Takeuchi, 'Implementing International Norms to Fight Against Terrorism — the 2014 Amendment of the Act on the Punishment of Financing of Offences of Public Intimidation' (2016) 58 Japanese Yearbook of International Law, 369 .

53 Duncan E. Osborne, 'The Financial Action Task Force and the Legal Profession' (2015) 59 N.Y.U. School of Law Review, 421, 426-427.

54 Article 7 (1) of the JFBA Rules provides: When a lawyer knows that the purpose relates to the transfer of criminal proceeds, obligations are imposed on the lawyer to persuade the client to refrain from the achievement of that objective. 
(Money Laundering) and Terrorist Financing Act, s.c. 2000, which makes lawyers subject to record-keeping and verification requirements, was met by a constitutional challenge launched by the Federation of Law Societies. The Supreme Court of Canada ruled that relevant provisions constituted a violation of Sections 7 and 8 of the Charter of the Bill of Rights and were of no force and effect in so far as they applied to lawyers..$^{55}$

Despite these challenges, the STR mechanism has been steadily infiltrating into the domestic legal orders of many jurisdictions. The case of Michaud $v$ France $^{56}$ of the European Court of Human Rights illustrates how such an infiltration operates at the stage of judicial review. In this case, the Court was faced with a question of whether a series of European Directives introducing the STR system was incompatible with Article 8 of the European Convention on Human Rights, in so far as the STR system applies to lawyers. The Court firstly observed that what Article 8 protects is 'the confidentiality of all the exchanges in which individuals may engage for the purposes of communication, ${ }^{57}$ and that requiring lawyers to report a suspicious transaction learned of through their correspondence constitutes an interference with a lawyer's right to respect their correspondence as well as their right to a private life. ${ }^{58}$ In assessing whether there was any justification for this interference, the Court addressed both the necessity and the proportionality of interference. As for the necessity test, the Court weighed a legal professional's privilege, ${ }^{59}$ protected under Article 8, against the importance that member states attach to combating the laundering of the proceeds of criminal activities, including international terrorism. In this regard, the FATF Recommendations were referred to as an example of a series of international instruments intended to prevent activities that constitute a serious threat to democracy. ${ }^{60}$ As for the proportionality test, the Court observed that the interference with professional privilege was not disproportionate, because the cases in which lawyers are subject to the obligation to report suspicions are limited ${ }^{61}$ and because the relevant legislation had introduced 'a filter which protects professional

\footnotetext{
55 Canada (Attorney General) v. Federation of Law Societies of Canada 2015 SCC 7 [FLSC].

56 Michaudv. France, ECHR, Application no.12323/11, Judgment of 6 December 2012.

57 Ibid, para. 90.

58 Ibid, para. 91.

59 According to the Court, this privilege is 'one of the fundamental principles on which the administration of justice in a democratic society is based'. Ibid, para.123.

6o Ibid. It should be noted that the FATF Recommendation was referred to alongside with the Council of Europe's Convention of 16 May 2005 on Laundering, Search, Seizure and Confiscation of the Proceeds from Crime and on the Financing of Terrorism. 
privilege, ${ }^{\prime}{ }^{2}$ in that lawyers are only required to directly report suspicions to the President of the Bar Council of the Conseil d'Etat and the Court of Cassation or the Chairman of the Bar of which they are a member and they are not required to report to governmental authorities. It is the President of the Bar Council that decides whether or not information should be transferred to the authorities. ${ }^{63}$ As a result of these factors the Court found that there had been no violation of Article 8 of the European Convention on Human Rights.

In the Michaud $v$ France, the relevant FATF Recommendation was referred to as one of the yardsticks against which the necessity of interference with the fundamental principles would be assessed. Because they are considered as the source of obligation to combat activities that pose a serious threat to democracy, which is considered equally fundamental, it could be argued that the FATF Standards serve to 'relativize' the value of legal professional privilege. Recalling that the FATF Standards are referred to as 'applicable international standards to be taken due account of' in the Council of Europe Convention on Laundering, Search, Seizure and Confiscation of the Proceeds from Crime and on the Financing of Terrorism, this can be seen as a side-effect of the positive reference at the stage of incorporation.

To sum up, the three features of the FATF Standards (non-binding nature, depth in substance and strength in structure) contribute to the facilitation their effective domestic implementation. Notably, it is the managerial aspect (the nonstate actor dimension) of the FATF that corresponds to the structure in the above framework that generates material consequences domestically; this feature is further amplified by the corresponding efforts of governments to promote the implementation of the FATF Standards. Given that the FATF Standards are made applicable within over 19o jurisdictions through the FATF's regional cooperative bodies, the effective domestic implementation would eventually lead to the harmonization of domestic legislation across states without the involvement of any treaty body. Building on this assessment, the next part of this Chapter will focus on the impact of such harmonization upon the international law-making process.

\subsection{Impact of the Harmonization of Domestic Legislation on the International Law-Making}

Another managerial aspect (non-state actor dimension) of the FATF is its 'external' capacity to spread its norms globally. As has been previously observed,

$62 \quad$ Ibid, para.129.

63 In this regard, lawyers' associations are granted a dual function in the sense that while they serve to protect their members against a direct intervention from state power, they also play a role of 'buffer' for the STR system in certain contexts. 
some FATF Standards mirror or enhance the provisions of the Terrorist Financing Convention. Thus, while the FATF Standards as non-binding international norms do not fall under traditional sources of international law as set out in Article 38 of the Statute of International Court of Justice, the harmonization of domestic legislation by implementing the FAT F Standards across states will substantially impact the existing norms under the Convention.

As for the mirroring provisions, the harmonization of domestic legislation will bring about the assimilation of conduct among states concerning the interpretation of the Convention.This is illustrated by the confrontation between the FATF and Japan over the definition of 'fund' wherein Japan eventually came to accommodate the FATF's position through its own actions. A proliferation of such actions may contribute to 'standardizing' the interpretation of the Convention without involvement of any treaty bodies or even the formal consent of states. ${ }^{64}$

This phenomenon of standardized interpretation generates an effect equivalent to that of 'subsequent practice' in relation to the interpretation of treaties enshrined in Article 31 of the Vienna Convention on the Law of Treaties. Indeed, some commentators argue that non-binding international standards albeit not meeting the threshold of international law - may nevertheless have certain legal effects, and suggest that these standards would be referred as a 'subsequent practice' in the interpretation of a treaty. ${ }^{65}$ However, it could still be argued that the standardization of interpretation generated by the domestic implementation of the FATF Standards may not be captured by the category of 'subsequent practice' in relation to the interpretation of treaties. According to the recent work of the International Law Commission (ILC) on this topic, ${ }^{66}$ in order for harmonized state action to fall into the category of 'subsequent practice', however identical the action is, it should meet the requirement of 'the agreement of parties regarding the interpretation of the relevant treaty'. While 'the agreement of parties' requires a 'common understanding regarding the interpretation of a treaty which the parties are aware of and accept',67

64 This marks a stark contrast with other fields of international law, especially human rights law, where a treaty monitoring body and state parties are sometimes opposed with each other over an interpretation of treaty provisions.

65 Joost Pauwelyn, Ramses A. Wessel, and Jan Wouters, 'When Structures Become Shackles: Stagnation and Dynamics in International Lawmaking' (2014) 25 European Journal of International Law, 733, 756-757.

66 International Law Commission, Draft conclusions on subsequent agreements and subsequent practice in relation to the interpretation of treaties, with commentaries [hereinafter Draft conclusions on SASP], UN Doc. A/73/10 (2018).

67 Draft conclusions on $S A S P$, p.75 (Conclusion 10). 
harmonized state action may not qualify as such an 'agreement', because the action takes place outside the realm of the treaty system and hence cannot constitute an understanding 'regarding the interpretation of a treaty'.

The ILC's work further suggests that pronouncements of expert treaty bodies may 'give rise to, or refer to, a subsequent agreement or subsequent practice by parties' 68 on the condition that these pronouncements are widely accepted by the parties of the treaty. ${ }^{69}$ While the FATF Standards are being proliferated worldwide through the regional cooperative bodies, the FATF may not qualify as an expert treaty body in the first place and hence may not produce any relevant 'pronouncements'.

As for the enhancing provisions, it could be argued that harmonization of domestic implementation reflecting these provisions would eventually 'adapt' treaty systems in order to meet new challenges. Admittedly, there is no normative link between the Terrorist Financing Convention and the FaTF Standards. However, the FATF Standards that govern customer due diligence are, in substance, built on the relevant provisions of the Convention, and in fact the domestic implementation of the Standards is in many cases brought about by amending the Convention implementing legislation. ${ }^{70}$ Therefore, the harmonization of amended legislation may ostensibly generate an 'adapting' effect of the Convention. Again this can be achieved without any recourse to the treaty amendment procedure, which often involves long and complicated negotiation and also requires state consent for it to be effective.

In this regard, it should be pointed out that modern treaty practice has developed a mechanism to 'mitigate' the strict requirement of consent in order to enable treaty systems to respond to changes in international society more rapidly and efficiently. For instance, some treaties introduce an 'opt out' clause in the amendment procedure, in which the effects of amendment apply to any state parties unless they express an objection to be bound by it. The International Convention for the Regulation of Whaling ${ }^{71}$ provides one of the earliest

68 Draft conclusions on SASP, p.106 (Conclusion 13).

69 Draft conclusions on SASP, p.110 (commentary to Conclusion 13). See also Whaling in the Antarctic (Australia v. Japan: New Zealand intervening), Judgment, I.C.J. Reports 2014, p. 257 [83] (observing that the International Whaling Commission resolutions adopted without the support of all States parties to the Convention cannot be regarded as subsequent agreement nor as subsequent practice).

70 For instance, the expansion of the scope of the STR system required by the FATF Standards has been done in many states by the amendment of the domestic implementing legislation of the Terrorist Financing Convention.

71 International Convention for the Regulation of Whaling, adopted 2 December 1946, entered into force 10 November 1948, 161 UNTS 72. 
examples. The Convention establishes an International Whaling Commission (IWC) which is entitled to amend, by a three-fourth majority vote, the Convention Schedule with respect to the conservation and utilization of whale resources. These amendments become effective for all parties except if a state party objects within ninety days. In that case, any parties that have not presented objection within 180 days of adoption of the amendment would become bound by these amendments. This approach has been followed by many treaty systems, especially those in the field of environmental law. ${ }^{72}$

The 'opt-out' procedure thus allows for dispensing with a formal procedure of ratification of the amendment by state parties, which facilitates rapid entry into force of the amendment, while leaving states an option not to be bound by the amendment. That said, it should be noted that the amendment under an 'opt out' clause is still anchored in a consent-based system, in the sense that silence can amount to consent. Put differently, it requires a 'manifestation' of state's will, however thin that would be. Conversely, the domestic implementation of the FATF Standards bypasses such requirements both at the international and domestic levels, while achieving the adaptation of treaty systems.

The foregoing observation illustrates that the harmonization of domestic legislation implementing the FATF Standards has generated effects that have had a substantial impact on the existing system of the Terrorist Financing Convention: effects that can be regarded as a 'standardization' of interpretation of the Convention or effects that may adapt the treaty system to today's challenges. While these effects are originally expected to be produced through existing treaty systems, the implementation of the FATF Standards may achieve the same result without recourse to the means or procedures within that system. Such phenomenon is hardly captured by the existing treaty system, as the latter is still anchored in a consent-based understanding of international law. ${ }^{73}$ Put differently, while the FATF's non-state actor dimension helps to spread its

72 Convention on International Trade in Endangered Species of Wild Fauna and Flora, adopted 3 March 1973, entered into force 1 July 1975, 993 UNTS 254; Vienna Convention for the Protection of the Ozone Layer, adopted 22 March 1985, entered into force 22 September 1988, 1513 UNTS 330; Basel Convention on the Control of Transboundary Movements of Hazardous Wastes and their Disposal, adopted 22 March 1989, entered into force 5 May 1992, 1673 UNTS 126.

73 Duncan B. Hollis, 'Why State Consent Still Matters - Non-State Actors, Treaties, and the Changing Sources of International Law' (2005) 23 Berkeley Journal of International Law, 137, 173. See also, Enrico Milano and Niccolò Zugliani, 'Capturing Commitment in Informal, Soft Law Instruments: A Case Study on the Basel Committee' (2019) 22 Journal of International Economic Law, 163, 176. 
Standards globally and thus affect the existing international norms, the FATF itself remains invisible as a law maker.

In a booklet published in 2019 for the 3oth anniversary of its foundation, the FATF describes itself as having evolved 'from a time-bound task force to an international organisation whose work was crucial to the integrity of the global financial system (emphasis added) $\cdot{ }^{74}$ However, the renewed Mandate issued in the same year maintains that 'the FATF has evolved from a temporary forum to a sustained public and political commitment to fight money laundering, terrorist financing, and proliferation financing (emphasis added) ${ }^{\prime}{ }^{7}$ This self-perception that oscillates between an international organisation (a non-state actor) and a commitment (an 'aggregate' of the wills of the member states) seems to reflect a twilight status for the FATF within the existing international legal system.

It is precisely this dual nature of the FATF that has made it one of the most successful models for international standard-setters. Its informality, attributed to its nature as a governmental network, allows it to make rapid decisions by dispensing with the strict requirement of state consent ${ }^{76}$ and secures its functionality. ${ }^{77}$ Meanwhile, its non-state actor dimension helps it effectively implement its standards and spread globally. ${ }^{78}$

Indeed, the FATF Standards have compensated for deficiencies in the Terrorist Financing Convention and have become increasingly dominant in combatting terrorist financing; however, this phenomenon raises questions of accountability. ${ }^{79}$ While the impact of the FATF's Standards equates to that of treaties and

74 FATF, Financial Action Task Force - 30 years, available at: https://www.fatf-gafi.org/ media/fatf/documents/brochuresannualreports/FATF3o-(1989-2019).pdf (accessed o9/ 03/20).

75 FATF's Mandate (12 April 2019), available at: http://www.fatf-gafi.org/media/fatf/content/ images/FATF-Ministerial-Declaration-Mandate.pdf (accessed o9/o3/20).

76 Pauwelyn, Wessel, and Wouters, note 65, 749.

77 Wouter G. Werner, 'State Consent as Foundational Myth' in Catherine Brölmann and Yannick Radi, Research Handbook on the Theory and Practice of International Lawmaking (Edward Elgar, Cheltenham, 2016), 13, 27.

78 Peter Hägel, 'Standard setting for capital movements: reasserting sovereignty over transnational actors?' in Anne Peters, Lucy Koechlin, Till Förster et al, Non-State Actors as Standard Setters (Cambridge University Press, New York, 2009), 352, 36o.

79 Ayelet Berman and Ramses A Wessel, 'The International Legal Form and Status of Informal International Lawmaking Bodies: Consequences for Accountability' in Pauwelyn, Wessel, Wouters, note 4, 57. See also Anne-Marie Slaughter, 'Disaggregated Sovereignty: Towards 
affect individuals' rights, they are agreed upon among government officials who are not directly accountable to their nationals nor vested with powers to express consent as a state. Regarding this, the dual nature of the FATF makes it invisible at both the international and domestic level, which increases the difficulty of recognising it as an actor that can be held accountable for its activities. ${ }^{80}$

It remains to be seen whether and how the FATF's functionality and effectiveness can be reconciled with the accountability requirement. Recognising the non-state actor dimension of the FATF seems to provide a good starting point for future discussion.

\section{Select Bibliography}

Chris Brummer, Soft Law and the Global Financial System (2nd edn, Cambridge University Press, New York, 2015).

Kenneth Blazejewski, 'The FATF and its Institutional Partners: Improving the Effectiveness and Accountability of Transgovernmental Networks' (2008) 22 Temple International \& Comparative Law Journal, $1-61$.

Richard Collins and Nigel D. White, International organizations and the idea of autonomy (Routledge, Abingdon, 2011).

Stavros Gadinis, 'Three Pathways to Global Standards: Private, Regulator and Ministry Networks' (2015) 109 American Journal of International Law, 1-57.

Duncan B. Hollis, 'Why State Consent Still Matters - Non-State Actors, Treaties, and the Changing Sources of International Law' (2005) 23 Berkeley Journal of International Law, 137-174.

Joost Pauwelyn, Ramses A. Wessel, and Jan Wouters, 'When Structures Become Shackles: Stagnation and Dynamics in International Lawmaking' (2014) 25 European Journal of International Law, 733-763.

Joost Pauwelyn, Ramses A. Wessel, and Jan Wouters, Informal International Lawmaking (Oxford University Press, Oxford, 2012).

Kal Raustiala, 'The Architecture of International Cooperation: Transgovernmental Networks and the Future of International Law' (2002) 43 Virginia Journal of International Law, 1-92.

the Public Accountability of Global Government Networks' (2004) 39 Government and Opposition, 159 .

8o For the legal visibility of an actor in international legal system, see Janne E. Nijman, 'Non-State Actors and the International Rule of Law: Revisiting the "Realist Theory" of International Legal Personality', in Martin Noortmann and Cedric Ryngaert, Non-State Actors Dynamics in International Law (Ashgate, Surrey, 2010), 91, 119. 
Kal Raustiala, 'Form and Substance in International Agreements' (2005) 99 American Journal of International Law, 581-614.

Ramses A Wessel, 'International Governmental Organisations as Non-State Actors' in Math Noortmann, August Reinisch, and Cedric Ryngaert, Non-State Actors in International Law (Hart Publishing, Oxford, 2015), 185-203. 